\title{
Wybrani Ojcowie Kościoła wobec filozofii starożytnej (cz. II)
}

\author{
ks. diakon Lukasz Leonkiewicz
}

lukasz_leon@poczta.onet.pl

ks. diakon Łukasz Leonkiewicz, Selected Fathers of Church about Ancient Philosophy (part II), Elpis, 16 2014: 75-86 .

\begin{abstract}
Christian theology often is called Christianized philosophy. However, in the early centuries of Christianity, its writers did not refer to ancient philosophy positively. For them, philosophy was a relic of paganism and its teachings were treated as vain and empty views. The first Christian writers had to confront philosophy and so many of them wrote about it either critically or positively. The Apostle Paul first came into contact with philosophers during his stay in Athens. Apologists then went on to write about the ancient philosophers and the Fathers of the Church drew inspiration from their thought as well. In their opinion, theology and philosophy differed from each other like truth from belief. Revealed in Scripture, the knowledge of God is truth, because it was proclaimed by the Prophets and Apostles, who were inspired of the Holy Spirit. They did not speak from themselves, but it was God who spoke through them. Philosophers, however trusted their own reason when they were seeking knowledge about the beginning of time, about truth, about God etc. Since the first century, Christian theology and philosophy saw this bond of "mutual understanding" that has united them to this day.

Streszczenie: Często spotykamy się z określaniem teologii patrystycznej jako „schrystianizowanej filozofii”. Jednak sama filozofia nie była postrzegana jednoznacznie pozytywnie przez pisarzy chrześcijańskich. Jedni przestrzegali przed filozofią, drudzy z kolei zachęcali do jej studiowania. Od momentu wizyty apostoła Pawła na Aeropagu rozpoczął się dialog myśli chrześcijańskiej ze starożytną myślą grecką. Metodą filozoficzną posługiwali się niektórzy apologeci, Ojcowie Kościoła, którzy w filozofii starożytnej dostrzegali wspaniałą szkołę myślenia dla chrześcijan. W ich wykonaniu filozofia była jednak podporządkowana objawieniu i Pismu Świętemu, dzięki czemu uzyskiwała status absolutny. Samodzielność filozofii i filozofów, którzy dążą do poznania prawdy własną ścieżką, zawsze była postrzegana jako zbytnia ufność własnemu rozumowi, pycha. Niedająca się usunąć więź filozofii starożytnej i teologii wschodniej, przez negację bądź zachwyt, do dziś napędza twórczość teologiczną i ożywia myśl prawosławną.
\end{abstract}

Keywords: theology, philosophy, ancient culture, father of church, the revelation of God, rational cognition, the Bible, the mind

Słowa kluczowe: teologia, filozofia, kultura antyczna, Ojcowie Kościoła, objawienie Boże, poznanie rozumowe, Biblia, umysł

Etap działalności Ojców Kościoła jest najpłodniejszym i najważniejszym okresem w historii rozwoju chrześcijaństwa. Spuścizna owych najbardziej światłych umysłów stała się fundamentem teologii chrześcijańskiej i punktem odniesień kolejnych teologów i pisarzy chrześcijańskich. Wypracowana przez kapadocczyków metoda teologiczna, charakteryzująca się przedefiniowaniem pojęć filozoficznych i nadawaniem im nowego, chrześcijańskiego sensu, jest do dziś aktualna w teologii prawosławnej. Polega ona na uchwyceniu w pojęciach greckich doświadczenia Boga przez człowieka. Myśl chrześsijańska, a w bezpośredni sposób teologia prawosławna, nie jest jedynie dyskursem spekulatywnym o Bogu, nie jest oderwaną od rzeczywistości nauką, która pretenduje do jej kategorycznego przyjęcia. Dogmat zawsze jest wtórny wobec jego doświadczenia w życiu duchowym, jest bowiem sformułowaną definicją doświadczenia mistycznego. Dogmaty powstały dopiero w sytuacji, gdy zagrożona była czystość chrześcijaństwa. Czystość ta zaś nie dotyczy sformułowanej nauki, bo takowej jeszcze nie było, ale relacji człowieka wobec Boga, doświadczenia Boga w Kościele, które przez pojawiające się herezje było deformowane i prowadziło do daleko idących konsekwencji. Za przykład może nam posłużyć osoba, wspomnianego powyżej Tertuliana. Mimo swej gorliwości $\mathrm{w}$ wierze i bezkompromisowej postawy, którą można porównywać do postawy pierwszych męczenników chrześcijańskich, nie został przez Kościół uznany za świętego, ani nawet za błogosławionego, jak np. Augustyn. Bronił chrześcijaństwa, choć w istocie jego poglądy miały wynaturzony charakter, pozbawionym łaskawości i miłosierdzia, które od zawsze charakteryzowały chrześcijan. Jego nauka o pokucie, choć bardzo szlachetna i duchowo elitarna, nie została jednak przyjęta przez Kościół, który z Chrystusową wyrozumiałością i miłością odniósł się do wszystkich chcących powrócić na drogę prawdy. Styl Tertuliana nie został przyjęty przez chrześcijan, bo był im obcy, co nie znaczy, że fundamentalnie przeciwstawny. Nauka moralna Tertuliana godna jest podziwu, tym bardziej przez współczesnych, zliberalizowanych chrześcijan, ale jej konsekwencje, o których wiemy z przykładu samego Tertuliana, oddalają ją od orthodoksii.

Myśl prawosławna (bo przecież, począwszy od IV-go wieku, rozpoczyna się proces rozdzielania się chrześcijańskiego Wschodu z Zachodem, polegający na obraniu różnych podstaw dla rozwoju teologii) jest syntezą praktyki i teorii, a konkretniej konceptualnym wyjaśnieniem tejże praktyki. Twórczość Ojców posiada status absolutny, bo przecież $\mathrm{w}$ epoce soborów powszechnych dokonało się uformowanie nauki chrześcijańskiej, jej metody i języka. Istnieje jednak drugi aspekt absolutnego charakteru tradycji patrystycznej. Teologia w prawosławiu nie jest traktowana jako dyscyplina akademicka, której można się nauczyć. Stanowi raczej formę praktyki religijnej, uczestnictwa w mistycznym i charyzmatycznym życiu Kościoła, polegającym na żywej pamięci, żywej więzi współczesnych uczestników z poprzedzającymi ich nauczycielami. Teologia, a ściślej bo- 
gosłowije, jest synonimem theorii, stanowi wyższy poziom doświadczenia duchowego, które jest przekazywane w tradycji, w Kościele. Wytworzona w ten sposób więź realizuje się poprzez przekazywanie ducha i myśli Ojców, polegającej na twórczym opisaniu objawienia się Prawdy.

Ojcowie stanęli przed nie lada wyzwaniem. Musieli stworzyć język teologiczny, w którym precyzyjnie można byłoby wyjaśnić istotę chrześcijaństwa, musieli odnaleźć się w filozoficzno-mitologicznej kulturze greckiej, odpowiedzieć na jej wyzwania, a zarazem nie zagubić $\mathrm{w}$ tym wszystkim wyróżniającej chrześcijaństwo prawdy, jaką jest Bogoczłowieczeństwo Chrystusa. Przy wypracowywaniu nowego dyskursu należało posłużyć się językiem już obecnym w kulturze greckiej, którym był filozoficzny język Sokratesa, Platona i Arystotelesa, który zawierał pojęcia wykorzystane przez Ojców do opisania prawdy chrześcijańskiej.

W twórczości Ojców Kościoła problem relacji filozofii do teologii był może nie wiodącym, ale dosyć ważnym, ponieważ korzystając z pojęć filozoficznych należało także ustosunkować się do tego, co one oznaczały w filozofii, z drugiej zaś strony trzeba było wyraźnie umiejscowić filozofów starożytnych w życiu chrześcijaństwa. Początkowo sytuacja filozofii nie była wcale korzystna, Ojcowie, tak jak wcześniej apologeci, odrzucali systemy filozoficzne starożytnych myślicieli, ale ciągle garściami czerpali z dorobku filozofów. Przyjrzyjmy się zatem jak wybrani Ojcowie Kościoła postrzegali tę kwestię.

\section{1. Św. Klemens Aleksandryjski}

Mimo, iż św. Klemens (ok. 150 - 212), z uwagi na lata życia, nie należy do grona pisarzy patrystycznych, to jednak w rozważanym przez nas problemie jak najbardziej wśród nich możemy go umieścić. Tworzy bowiem pewien systematyczny obraz myśli chrześcijańskiej, w którym relacja filozofia-teologia zajmuje ważne miejsce.

Już na początku swych „Kobierców” sygnalizuje, że będzie się odwoływał do filozofii greckiej. Jego liczne nawiązania do platońskich „Dialogów” oraz do innych dzieł tegoż filozofa sugerują, że aleksandryjczyk zamierza wejść $\mathrm{w}$ dialog z filozofami i w swej nauce stworzyć kolorowy, złożony z różnych elementów kobierzec, symbolizujący naukę chrześcijan.

Klemens zauważa, co jest cechą wspólną wszystkich Ojców, że chrześcijanie muszą po sobie pozostawić owoc swego istnienia, nie w postaci materialnej, ale powinien to być owoc duszy, czyli „twórczość umysłu”. Zauważalnie potrzeba intelektualnego objaśnienia swej wiary dokonuje się wraz z uwzględnieniem sytuacji intelektualnej epoki, chrześcijaństwo jest zwieńczeniem dotychczasowej filozofii, jak również zwieńczeniem całokształtu kultury grecko-rzymskiej. Klemens nie boi się filozofii, tak jak Justyn, a nawet cytuje i powołuje się na filozofów, bo przecież

\footnotetext{
Klemens Aleksandryjski, Kobierce, t.1, Instytut Wydawniczy Pax, Warszawa 1994, s. 2.
}

z filozofią jest podobnie jak z orzechami, „nie cała jest do spożycia”. Tłumacząc czym jest chrześcijaństwo, korzysta z poglądów różnych pisarzy, zarówno chrześcijańskich jak i niechrześcijańskich, bo w służbie Bogu wszystko może być ofiarowane. Klemens nie przedstawia całościowych poglądów innych filozofów, ale tworzy nowy system, opisuje chrześcijaństwo, jako nową naukę, w swej istocie nieobecną $\mathrm{w}$ dotychczasowej historii. Istnieli pisarze natchnieni przez Boga, jakimi byli prorocy, jak również natchnieni przez proroków, jakimi byli filozofowie, a dokładnie Platon ${ }^{3}$. Aleksandryjczyk podobnie jak jego poprzednicy uważa, że Platon znał Stary Testament, ale twierdził między innymi, że Bóg w różnoraki sposób objawiał się w historii. Klemens uważa siebie za kontynuatora dzieła apostołów, tyle że jego zawierać będzie „Prawdę, nie w stanie czystym, lecz wymieszaną z teoriami filozoficznymi, a raczej zasłoniętą przez nie i ukrytą w ich głębi, podobnie jak miąższ jadalny w łupinie orzecha"4. Nie osądza on filozofów i filozofii starożytnej, a podkreśla jej znaczenie w Bożym planie zbawienia. Jak u nikogo wcześniej pojawia się u Klemensa myśl o nieodrzucaniu dorobku kultury, a o jego przetworzeniu. Autor „Kobierców” oburza się wręcz na tych, którzy głoszą absolutny sceptycyzm wobec mądrości pogan. Uważa on bowiem takich ludzi za „tchórzliwych ignorantów"', bo przecież to, co jest z natury złe, nie może niczego dobrego wytworzyć, a filozofia $\mathrm{w}$ wielu miejscach ukazuje na prawdę, dlatego „będę dawał do zrozumienia, - mówi on - że także filozofia jest w jakiejś mierze dziełem boskiej Opatrzności"'. Filozofia jest wprowadzeniem człowieka do prawdziwego poznania, mówi za pomocą obrazów o tym, co bezpośrednio głosi chrześcijaństwo. Nie można jej odrzucić, nie dokonawszy przedtem pełnej weryfikacji, bo będzie to niesłusznym osądem. Oskarżać filozofii za jakąś szkodę, którą ma wyrządzać chrześcijanom, nie można, bo zapoznawszy się z nią zauważymy, że ona „nie niszczy życia, ..., a jest przejrzystym obrazem prawdy, boskim darem ofiarowanym Hellenom"', podobnież nie można jej oskarżać o zabieranie ludziom wiary, bo „korzystając dzięki niej $\mathrm{z}$ tym silniejszego poparcia uzyskujemy wspólną zaprawę myślową w wykazywaniu słuszności naszej wiary"s. Znajomość filozofii pomaga w zrozumieniu chrześcijaństwa i w jego zdefiniowaniu. Klemens podejmuje temat, który twórczo podraktują późniejsi Ojcowie, którzy dzięki terminom filozoficznym dokonają analizy i wykładu wiary chrześcijańskiej. Wiedza wypływająca z zestawienia różnych teorii filozoficznych pozwala uchwycić prawdę, nieobecną w pełni w żadnej z tych teorii. Filozofia pełni więc u niego służebną funkcję wobec chrześcijańskiej myśli, po ciężkim wysiłku analizy poglądów filozofów, zgłębia prawdę, która swe piękno odsłania dopiero po uciążliwej drodze ku niej. Aleksandryjczyk potępia postawę tych, którzy bez

\footnotetext{
Tamże, s. 5.

Zob. Tamże, s.7.

Tamże, s. 13.

Tamże.

Tamże, s. 14.

Tamże.

Tamże, s. 15.
} 
zastanowienia potępiają i odrzucają filozofię, wymaga ona bowiem zaangażowania intelektualnego w tematykę wiary, i to właśnie umożliwia filozofia. Rozważając o filozofii Klemens rozróżnia dwa rodzaje skutków jakie w człowieku wywołuje filozofia i Pismo.

Cytując proroków stwierdza, że Pismo Święte uczy wrażliwości duchowej, dzięki której możliwe jest poznanie Boga. Klemens ma świadomość, że do czego innego wzywają prorocy, a do czego innego filozofowie, pierwsi uczą strachu Bożego, drudzy zaś czujności rozumu. Prorocy i apostołowie uczą o wyższości wrażliwości duchowej nad wrażliwością filozoficzną, czyli nad aktywnością rozumu, pouczają w Piśmie o prymacie strachu Bożego nad postawą pysznej pewności. Jednak pisarz z Aleksandrii zauważa, że filozofia może przygotować duszę do tej wrażliwości duchowej: „Ci bowiem, których filozofia uczyniła sprawiedliwymi, mają też rezerwę pomocy - jest nią wrażliwość umysłowa, skierowana ku bojaźni Bożej”9. Jest tak, bo to sam Bóg, jego zdaniem, ustanowił filozofię jako wstęp do świadomej wiary. Klemens widzi realną groźbę spłycenia chrześcijaństwa przez niewykształconych chrześcijan, którzy swą postawą mogą mu wyrządzić krzywdę i przysporzyć powodów do oskarżania chrześcijan przez pogan. Filozofia dostarcza narzędzi poznawczych, dzięki którym można dokładnie zidentyfikować prawdę chrześcijańską i dzięki którym możliwe jest merytoryczna obrona wiary chrześcijan przed zarzutami tych, którzy czekają na okazje do krytyki. Cytując słowa Salomona o zdobywaniu mądrości Klemens mówi, że to przecież filozofia „przyczynia się do nabywania mądrości”"10, a dalej pisze, że „filozofia ma jako cel poszukiwanie prawdy i istoty bytów (taka to prawda, o jakiej sam Pan mówi: „Jam Prawda”); z drugiej strony wstępne przygotowanie do wytchnienia w Chrystusie ćwiczy umysł, budzi świadomość, rozwijając bystrość, zdolną do poszukiwania prawdziwej filozofii"11, którą mogą posiąść jedynie wtajemniczeni. By zajmować się prawdą chrześcijańską należy przygotować umysł, co umożliwia filozofia. Jest ona zatem ćwiczeniem umysłu, przygotowuje człowieka do rozważania o sprawach najwyższych. Innym powodem, dla jakiego należy zajmować się filozofią, jest możliwość odparcia fałszywych poglądów sofistów, czyli tych, którzy pyszniąc się swoją krasomówczością, głoszą nauki kłamliwe, okradające rzeczywistość z prawdy. Klemens traktuje filozofię identycznie jak Platon, jest ona dla niego umiejętnością prawidłowego myślenia, wychwytywaniem istoty rzeczy z wszelkich możliwych stron. Dopiero tak rozumiana filozofia doprowadza człowieka do zdobycia wiedzy, która podtrzymuje i wzmacnia wiarę. Aleksandryjczyk zaleca ćwiczenie się w filozofii każdemu, choć jest świadom, że prorocy i apostołowie nie przez ćwiczenie rozumowe zdobyli wiarę i nauczyli się ją argumentować, ale przez obecność w ich sercach Ducha Bożego. Klemens podkreśla moment natchnienia i uznaje jego wyższość, jed-

\footnotetext{
Tamże, s. 19.

10 Tamże, s. 22.

11 Tamże, s. 24.
}

nak zauważa także potrzebę wysiłku człowieka, jego trudu ku zrozumieniu tajemnic wiary.

Filozofia jest ćwiczeniem potrzebnym człowiekowi, ale nie powinna stać się ona dla niego próżną sztuką erudycyjną, bo w takim wypadku przestanie być filozofią, a zacznie być sofistyką. Klemens podkreśla, że dopiero tak przygotowany człowiek może zająć się analizą poglądów starożytnych myślicieli, bowiem dopiero wtedy będzie można dostrzec prawdę chrześcijańską rozproszoną w filozofii greckiej. Niepoprawnym jest to, że „różne szkoły filozoficzne, barbarzyńskie i helleńskie, chwalą się, że ten ułamek prawdy, który każdej z nich przypadł w udziale, to już cała prawda”"12, bo „filozofia barbarzyńska i helleńska wieczną Prawdę rozerwała na części, które jednak nie należą do mitu o Dionizosie, lecz do nauki Bożej o Słowie wiecznie istniejącym"13. W pochwale filozofii nie ma jednak mowy o prymacie nad Pismem Świętym, to przecież ze Starego Testamentu pochodzą częściowe prawdy obecne w filozofii, bo myśl helleńska zawdzięcza prawie wszystko myśli hebrajskiej, jako wcześniejszej od niej. Taki pogląd Klemens argumentuje tym, iż po przetłumaczeniu Pisma Świętego na język grecki, Grecy poznali proroctwa starotestamentowe. Filozofia helleńska jest etapem przygotowawczym do przyjęcia chrześcijaństwa, dlatego, że „w filozofii tkwi ślad mądrości Bożej i impuls w stronę Boga"14, który choć sam nie wystarczy do poznania prawdy, jest wartościowym pomocnikiem wiary.

Chrześcijanin powinien dążyć do szczęścia, o którym wspomina Pismo Święte. Wcześniej przytacza jednak poglądy platończyków, stoików i innych na temat celu życia człowieka. Pokazuje, że tkwi w nich źródło nauki o cnocie, pokorze, wewnętrznej doskonałości. Rozwinięciem i wypełnieniem etyki filozoficznej jest chrześcijaństwo, które do maksimum rozszerza naukę o doskonałości człowieka. „Naszym jednak zadaniem - pisze on - jest uzyskać koniec, nie mogący mieć końca, mianowicie w posłuszeństwie przykazaniom, to znaczy Bogu, przeżyć życie według nich, nienagannie i świadomie, w pełnym zrozumieniu Boskiej woli"15. Takie życie daje możliwość usprawiedliwienia, upodobnienia się do Boga, co powinno stanowić wypełnienie bytu ludzkiego.

Filozofia jest dla Klemensa elementem ważnym na drodze do poznania objawienia chrześcijańskiego. Umożliwia zrozumienie chrześcijaństwa, rozwija człowieka, przygotowując go do przyjęcia prawdy objawionej. Aleksandryjczyk jest jednym z nielicznych pisarzy chrześcijańskich, którzy w taki sposób wyrażają się o filozofii. Z pewnością bierze się to z tego, że był dobrze wykształconym człowiekiem, nie bał się rozważań filozoficznych, zaś obawiał się niedouczenia i powierzchownego potraktowania nauki chrześcijańskiej, co było możliwe w owym czasie (dzisiaj także). Klemens wyprzedza swoją epokę, porusza problemy charakterystyczne dla patrystyki, wchodzi w dialog z kulturą mu współczesną, wykazuje się gruntowną znajomością

\footnotetext{
12 Tamże, s. 43.

13 Tamże, s. 44

14 Tamże, s. 63.

15 Tamże, s. 218.
} 
problemów swojej epoki. Chce objawić chrześcijaństwo światu, stara się wytłumaczyć nie tylko poganom czym ono jest, ale nawet samym chrześcijanom zwraca uwagę na to aby nie poprzestawali na powierzchownym zrozumieniu wiary w Chrystusa, a postarali się o fundamentalne jej poznanie.

\section{Ojcowie kapadoccy}

W tym samym duchu, czyli w pełnym poszanowaniu filozofii i kultury helleńskiej, wypowiadają się najznakomitsze umysły IV wieku. Filozofowie, teolodzy, znawcy literatury klasycznej, a do tego asceci i pełni zaangażowania obrońcy chrześcijaństwa, jakimi byli święci: Bazyli Wielki, Grzegorz Teolog i Grzegorz z Nyssy. Ich dzieła przesiąknięte są filozofią, zarówno jeżeli chodzi o cytowanie filozofów, jak i o filozoficzność myślenia. Wykształceni w szkołach filozoficznych - Bazyli oraz Grzegorz z Nazjanzu w Akademii ateńskiej, Grzegorz z Nyssy w młodości trudnił się retoryką - postrzegali filozofię już nie apologetycznie, a twórczo. Dostrzegli w niej potencjał literacki i metodologiczny, którego rozwinięcie okaże się korzystne dla teologii, czyli filozofii chrześcijańskiej. Wydaje mi się, że analizując twórczość tych ojców nie można dokonywać drastycznego rozdzielenia filozofii i teologii, bowiem na tym etapie jeszcze się on nie dokonał. Poza tym, z pewnością, rozgraniczeniu tych dwóch sfer nie byliby oni przychylni, bowiem inaczej niż my postrzegali filozofię, której częścią była teologia.

Nie będziemy teraz analizować reinterpretacji pojęć, dokonanej przez Kapadocczyków, a jedynie spróbujemy wskazać w ich pismach miejsca mówiące o tym czym dla nich była filozofia i w jakiej relacji pozostawała wobec doświadczenia chrześcijańskiego. Ich nauka, angażująca filozofię do wyjaśniania chrześcijańskich tajemnic wiary, jest wyrazem dojrzałego, profesjonalnego i uczciwego podejścia do rozważanego przedmiotu. W IV wieku nie ma jeszcze teologii chrześcijańskiej jako takiej, ponieważ dopiero powstaje. Nie można jeszcze mówić o systematycznej teologii przedkapadockiej, ponieważ takowej nie było. Istniały nauki, opinie poszczególnych pisarzy, ale bardzo często różniły się one od siebie, poza tym w ich twórczości, niezbyt dokładnie wyłożono i opisano podstawy nauki chrześcijańskiej. Dogmaty, z przyczyn oczywistych, kształtują się dopiero w epoce soborowej, przy czynnym udziale filozofów-teologów chrześcijańskich, którzy przyczynili się do precyzyjnego opisania duchowego doświadczenia Boga.

Zaczynając od „przywódcy” Kapadocyjczyków, św. Bazylego Wielkiego, powinniśmy zwrócić uwagę na podejście jego i pozostałej dwójki do sofistyki. Sofiści, od czasów Sokratesa, byli lekceważeni przez pozostałych filozofów, nie uczyli bowiem właściwego myślenia, a jedynie odtwórczego przetwarzania zdobytej wiedzy. Niechęć do nich wzrastała tym bardziej, gdy odtwarzając poglądy filozofów sprowadzali filozofię do historii idei. Wyliczenie poglądów Sokratesa, Platona czy Arystotelesa miało być objawieniem prawdy i to $\mathrm{w}$ dodatku prawdy filozoficznej. Żaden z filozofów, jak również interesujący nas ojcowie, nie sprowadzali filozofii do historycznego odtworzenia nauk swych poprzedników i stwierdzenia, że to jest właśnie filozofia Jest ona metodą myślenia, a nie nauką, którą można zapamiętać i w razie potrzeby odtworzyć, jak chcieli sofiści. Bazyli, jako filozof nie może zgodzić się z takim nieodpowiedzialnym podejściem do filozofii. Krytykuje wszystkich tych, którzy bezrefleksyjnie odtwarzają opinie klasyków filozofii, nie postrzega jej jako czegoś zakończonego, jako etapu w historii, a traktuje ją jako metodę na życie, która może przybrać walory prawdziwości, w chrześcijaństwie, bądź oszustwa, jak współcześni Bazylemu heretycy i poganie. Natomiast filozofia starożytna była nauczycielką Greków przed przyjęciem objawienia, zawiera wiele wartości, które należy rozwinąć, natomiast pozostałe treści przeinterpretować, by w chrześcijaństwie stały się filozofią prawdziwą. Dlatego w „Heksameronie” odnajdujemy krytykę filozofów starożytnych, wyrażoną w odrzuceniu przez Bazylego ich kosmologicznych poglądów. Zarówno Platon, Arystoteles, także stoicy mylili się co do genezy świata materialnego, nie znali Boga, więc nie mogli znać prawdy. Jednak mimo to Bazyli dokonuje uaktualnienia prawdy objawionej w Piśmie Świętym. Ukazuje w „Heksameronie”, że naukę chrześcijańską można pogodzić z współczesnym mu stanem wiedzy naukowej. By tego dokonać posługuje się „Fizyką" Arystotelesa, nie poprzestaje na cytowaniu autora jego cytowaniu, a raczej zaczyna z nim dyskusję. Bazyli już w IV wieku, zauważa, że poglądy Arystotelesa po dokonaniu niewielkiej przeróbki można schrystianizować. $\mathrm{Na}$ długo przed Tomaszem z Akwinu dostrzega przydatność filozofii perypatetyckiej, jednak w odróżnieniu od niego nie przejmuje metody w pełni i nie dokonuje arystotelesowskiego wykładu chrześcijaństwa, a na odwrót, dopełnia chrześcijańskiego przetworzenia arystotelizmu, platonizmu i stoicyzmu. Bazyli koryguje wszystkie poglądy filozofów konfrontując je z Biblią, która jest dla niego objawieniem prawdy. Próbując pogodzić biblijny opis stworzenia z ówczesną nauką stwierdza, że Biblia nie została napisana w celu dokładnego wytłumaczenia przebiegu procesu stwarzania świata, ponieważ jej celem jest zbawienie człowieka i ten soteriologiczny aspekt Pismo podkreśla. W „Heksameronie" Bazyli sięga szczytów filozoficznych, polemizując ze starożytnymi kosmologiami ukazuje inny biblijny wymiar stworzenia. Dyskurs jego nie dotyczy jednak filozofii jako takiej, a jedynie jej owoców, które, co oczywiste, nie były, bo być nie mogły, chrześcijańskie.

W większości dzieł autorstwa św. Bazylego zauważamy odwołania do filozofii starożytnej, zaś jego język jest językiem filozoficznym. Przez cały czas Bazyli odnosi się z szacunkiem do filozofii, co $\mathrm{w}$ bezpośredni i dosłowny sposób można odnaleźć w krótkiej rozprawie zatytułowanej „Mowa do młodzieńców, jaki mogą odnieść pożytek z czytania książek pogańskich". Bazyli porusza w niej ważny problem, czy można czytać książki pogańskiego pochodzenia. Widocznie już w czasach wielkiego teologa w Kościele istniał problem recepcji myśli antycznej wśród chrześcijan. Edukacja w Cesarstwie Rzymskim opierała się na poetach i filozofach starożytnych, a lektura ich dzieł była obowiązkowa. Wiemy o tym chociażby z życia św. Bazylego, który 
w młodości studiował mądrość pogańską, zaś później, już jako biskup Cezarei, pisał listy do swego dawnego nauczyciela filozofii. W Cesarstwie istniała Akademia platońska, którą zamknięto dopiero w VI wieku, proces edukacji nie został od razu schrystianizowany, cenzura, której w czasach Bazylego jeszcze nie było, nie objęła dzieł pogańskich. Swięty starając się ukazać swoim wiernym prawidłowy i zalecany stosunek do dzieł antycznych, we wspomnianej powyżej rozprawie daje wyraz należytego szacunku wobec tego, co poprzedzało chrześcijaństwo.

Każdy człowiek mając nauczyciela nie powinien ślepo za nim podążać, ale nieustannie uważać, by wraz z nauczycielem nie zatracić się w nauce nieprawdziwej. Święty Bazyli, uznający starożytnych myślicieli za swoich nauczycieli, poucza młodych chłopców, by korzystali z ich mądrości $\mathrm{z}$ rozumem, nie przyjmowali wszystkiego lecz jedynie to, co najlepsze ${ }^{16}$. Dlaczego święty hierarcha sugeruje młodym ludziom by czytali księgi pogańskie? Bazyli uznaje, że młody umysł nie jest w stanie zrozumieć należycie głębi Pisma Świętego, a przecież powinien skądś brać przykłady moralności oraz rozwijać swoją wrażliwość wewnętrzną. Bazyli stara się zasugerować możliwie najbezpieczniejszą drogę, która przygotuje młodego człowieka do życia chrześcijańskiego. Pisze on, że przecież „w tę drogę wprowadzają nas, oczywiście, Święte Pisma, które uczą nas za pośrednictwem nauk mistycznych; jednak dopóki, z uwagi na wiek, nie możemy zgłębiać ich sensu, możemy w także w innych pismach, wcale od nich nie dalekich, ćwiczyć przez pewien czas oko duchowe"17. Przez wysiłek związany z zapoznaniem się i zgłębieniem literatury starożytnej można poznać, lepiej lub gorzej, cienie i obrazy nauki chrześcijańskiej. Zarówno u poetów, historyków i oratorów greckich, ale także i u filozofów, każdy może znaleźć coś pożytecznego dla własnej duszy, po czym łatwiej będzie można przejść do nauki Pisma. Bazyli zauważa, że w nauce starożytnych jest pewne pokrewieństwo, podobieństwo poglądów, które może nauczyć człowieka dostrzegania tego, co wartościowe i godne chrześcijanina. Pisze o tym następująco: „by nasza dobra sława na zawsze pozostała niezachwiana, poświęcając siebie dogłębnemu studiowaniu pisarzy powierzchownych, potem rozpoczniemy słuchania świętych i mistycznych lekcji, i jakby przyzwyczaiwszy się do oglądania słońca w wodzie, ostatecznie, zwrócimy wzrok ku samej światłości. Dlatego, jeżeli między poglądami dochodzi do pewnego wzajemnego pokrewieństwa, to ich poznanie okaże się nam pożyteczne. Zaś gdy to pokrewieństwo nie zachodzi, to studiowanie różnych poglądów, porównując je ze sobą, tym bardziej posłuży do potwierdzenia lepszej nauki"18. Nawet, gdy dusza człowieka nie otrzymuje nic pożytecznego od nauk świeckich, to ich znajomość pozwala na wykazanie i potwierdzenie wyższości nauki wyznawanej przez człowieka. Posługując się postaciami starotestamentowymi święty zaznacza, że nie można odrzucić nauk świeckich, bo przecież Mojżesz, przed objawieniem się mu

\footnotetext{
16 Zob. www.orthlib.ru/Basil/beseda22.html.

17 Tamże.

18 Tamże.
}

Boga, zapoznał się z mądrością egipską, a prorok Daniel, przed poznaniem Boga, w Babilonie nauczony został nauk

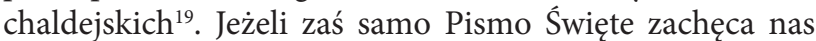
do tego, to nie należy pogardzać naukami filozoficznymi lecz je poznać i wziąć to, co wartościowe i godne pochwały. Podobnie jak w literaturze można znaleźć dobre przykłady bohaterów do naśladowania, także filozofowie takie postawy nam oferują. Bazyli opisuje postacie, które można naśladować, a są nimi Sokrates, Platon, Diogenes, Pitagoras. Głoszona przez nich pochwała cnoty, zachęta do duchowych i cielesnych ćwiczeń (ascezy) oraz nauka o wyższości pierwiastka niematerialnego w człowieku nad ciałem jest tym, co Bazyli uważa za najważniejsze. Przecież chrześcijanin powinien dążyć do doskonałości, a jeżeli o niej nauczali pogańscy filozofowie, to cóż pozostaje chrześcijanom, jeśli nie naśladowanie ich w tym wysiłku. Święty Bazyli jakby stara się powiedzieć, że wychowanie człowieka powinno zaczynać się od ukazania bliskiego mu wzorca, ale jednocześnie ukierunkowującego myśl młodego człowieka ku Bogu. Nauka jaką można odnaleźć w księgach pogańskich jest „odblaskiem cnoty” ${ }^{20}$, poucza młodych ludzi o odrzuceniu przyjemności zmysłowych i o ukierunkowaniu swych myśli ku Bogu. Dlatego kończąc swoją mowę do młodzieńców Bazyli podniesionym głosem zaleca: „Nie uciekajcie od ludzi, którzy rozmyślają sprawiedliwie!”21. Oczywiście biskup Cezarei mówi wyraźnie jakich pisarzy powinno się czytać, podpowiada, co u którego może pomóc młodemu człowiekowi w zrozumieniu chrześcijaństwa.

Do Bazylego Wielkiego powrócimy jeszcze, przy omawianiu jego zasług w tworzeniu filozofii chrześcijańskiej - teologii. Liczne odwołania do filozofów, jego filozoficzny umysł oraz chęć schrystianizowania ogólnie rozumianej kultury, w tym w szczególny sposób filozofii, świadczą o stosunku tego ojca Kościoła do filozofii. Od tego momentu rozpoczyna się droga współpracy rozumu i duszy, w myśli chrześcijańskiej, a w szczególności w myśli prawosławnej. Następni kapadocczycy, mając świadomość odrębności ich nauki od ją poprzedzającej, być może jeszcze mocniej będą podkreślać znaczenie filozofii dla chrześcijan.

Przyjacielem i „współpracownikiem” intelektualnym św. Bazylego był św. Grzegorz Teolog, który podobnie jak on był z wykształcenia filozofem. Od młodych lat fascynowała go nauka, jak sam o sobie napisał - „jeszcze pierwszy puch nie pokrył mych policzków, a już rozgorzała we mnie miłość do nauki. Dokładałem starań, by pogańską literaturę wprząc w służbę prawowiernych pism i żeby nie byli górą ci, co się niczego nie nauczyli oprócz pustosłowia i jałowego krasomówstwa, bulgotów wydobywanych z gardła, a i też - żeby samemu nie zaplatać się w sieci sofistyki”22. Bardzo podobna postawa do tej, którą prezentował św. Bazyli. Nie powinno to dziwić, bo przecież razem studiowali i w pełni się zgadzali w tych kwestiach. Jednak większe pragnienie samotności i ciągłe jej poszukiwanie, ucieczka

\footnotetext{
19 Zob. Tamże.

20 Tamże.

21 Tamże.

22 Św. Grzegorz z Nazjanzu, Opowieść o moim życiu, Wydawnictwo W drodze, Poznań 2003, s. 16.
} 
z Aten i kolejne w jego już biskupim życiu spowodowały, że przyjął bardzo zaangażowaną, egzystencjalną postawę wobec filozofii. Dlatego Grzegorz pisze, że przyjęta przez niego „filozofia polegała na tym, by nie popisywać się ćwiczeniem w doskonałości, ale by żyć w prawdziwej, a nie na pokaz przyjaźni z Bogiem"23. Filozofia jako rozmiłowanie się w mądrości była dla Grzegorza Teologa zbliżeniem się do Chrystusa, jedynej Mądrości, przylgnięciem nie tylko emocjonalno-duchowym, ale także intelektualnym oraz dawaniem świadectwa o tym, kogo się wybrało. Jego pisma są bardzo emocjonalne, jak również niesamowitym wkładem intelektualnym. Grzegorz wchodzi w dialog z filozofią starożytną w celu opisania nowej, chrześcijańskiej, filozofii.

W swych "Listach" biskup z Nazjanzu pokazuje, czym jest dla niego filozofia. $W$ tych osobistych rozmowach, za pośrednictwem pióra i papieru, pokazuje swoje rozumienie tej nauki Nie traktuje jej bowiem jako rozwijania teoretycznych dociekań, a zdecydowanie bardziej etycznie. Filozofia jest życiem zgodnym $\mathrm{z}$ własnymi zasadami i podtrzymywaniem ducha na wysokim poziomie i nie uleganiem czynnikom ciągnącym go w dół. Od razu nasuwa się nam wizja tego, co Grzegorz będzie podkreślał w filozofii starożytnej. Najważniejsze dla niego będą konsekwentne postawy i nauka etyczna filozofów greckich.

Pierwsze słowa wychodzące spod pióra Grzegorza Teologa na temat rozmiłowania w mądrości, dotyczą filozofii pieszej, przyziemnej². Filozof nie może dążyć do władzy, powinien być skromnym człowiekiem, tym bardziej nie chcieć żadnych godności kościelnych. Takie zasady odnajdziemy u stoików, których bardzo lubił święty Grzegorz. Filozofia głosi dobre, sprawiedliwe życie, zaś wszyscy ci, którzy się nią nie zajmują są sofistami, czyli ludźmi niepotrafiącymi żyć dobrze. Podobne myśli znajdujemy u Grzegorza, ponieważ ciągle poszukiwał on szczęścia dla swej duszy, które może mu dać jedynie dobre życie. Odwołując się do Platona sugeruje, że ten, kto chce się wyzwolić od nieszczęść musi zająć się filozofiąą, która jedynie umożliwia sprawiedliwe życie. Zazwyczaj wszystkie jego nawiązania do filozofów dotyczą sposobu życia, słabości adresatów albo krytyki ludzi źle postępujących. Filozofowie są wzorem moralnym, za którym warto podążać, doskonaląc się tym samym w chrześcijaństwie. Grzegorz za dewizę przyjmuje słowa Platona, że filozofia jest ćwiczeniem się w umieraniu ${ }^{26} \mathrm{i}$ właśnie taki stosunek człowieka do własnej śmierci rzuca cień na całą jego myśl filozoficzno-teologiczną. Życie jest służbą Bogu, a wszystko, co człowieka od tego odwodzi należy zanegować i pokonać zasadą ${ }^{27}$, która polega na tym, „by nie dbać o ciało, o cielesność, o wszystko, co płynne, bezładne i przemijające, całym sercem przystać do sprawy niebieskiej, by żyć - zamiast dla obecności - dla przyszłych

\footnotetext{
23 Tamże, s. 23,

24 Por. Św. Grzegorz z Nazjanzu, Listy, Jan Jachowski Księgarnia Uniwersytecka, Poznań 1933, s. 15

25 Por. Tamże, s 38.

26 Por. Platon, Dialogi, 64 a - 68 b, tłum. W. Witwicki, [w:] tegoż Dialogi, Unia Wydawnicza VERUM, Warszawa 2004, s. 233 - 238.

27 Zob. Św. Grzegorz z Nazjanzu, Listy, Jan Jachowski Księgarnia Uniwersytecka, Poznań 1933, s. 46.
}

przeznaczeń, uważając tutejszy żywot, jak mówi Platon, za zaprawianie się do śmierci i uwalniając duszę - wedle sił - od tego ciała czy, jak on to mówi - grobu"28. Nauka Platona jest bliska Grzegorzowi, z kolei krytykuje on Arystotelesa za małoduszność, polegającą na tym, że Stagiryta mimo, iż zrozumiał szczęście jako stan duchowy, to jednak uzależniał je od dóbr ziemskich. Tego właśnie nie uznawał biskup Nazjanzu, który wolał wzniosłą i piękną naukę stoików twierdzących, że nawet więziony i męczony człowiek może być szczęśliwym ${ }^{29}$. Jako przykłady ludzi szczęśliwych mimo przeszkód życiowych, Grzegorz podaje Sokratesa, Epikteta i Anaksarcha, a na końcu dodaje do nich „naszego Hioba" ${ }^{30}$. Te postacie są wzorami filozofów i w pełni ukazują czym jest filozofia, można dodać jeszcze, że są też dla Grzegorza osobistymi wzorami do naśladowania.

W wielu innych miejscach Grzegorz pisze o filozofii, jako o głębi, mądrości, cierpieniu, najlepszej sztuce ze wszystkich, a osobom zajmującym się filozofią zabrania jej porzucania $^{31}$. Innych także przestrzega przed tym, by Bóg ich „nie zastał niefilozofującymi i ziemskimi” ${ }^{\text {2 }}$, ponieważ godne chrześcijanina jest życie w doskonałości, w ciągłym ćwiczeniu swojego ciała i duszy, na czym właśnie polega cała filozofia. Mądrość Grzegorz rozumie jako sztukę życia, mającą doprowadzić człowieka do Boga, a świadomy tego wybór jest filozofią.

Choć św. Grzegorz nie pisze odrębnego dzieła na temat filozofii, to, podobnie jak i u św. Bazylego, jest ona ważnym składnikiem jego nauki. Interesujące jest to, że żaden z nich nie używa słowa teologia w odniesieniu do poznania Boga, ale właśnie słowa filozofia. Utożsamienie już w IV wieku Chrystusa z mądrością, okazuje się być trwałe i rzutuje na przyszłych Ojców. Filozofia jako droga do Boga, a nie pustosłowie, jest także powodem krytyki jaką w kierunku św. Grzegorza z Nyssy wystosował Grzegorz Teolog.

Święty Grzegorz z Nyssy określany jest często jako najbardziej filozoficzny spośród kapadocczyków. Przez długi okres był retorem, nawet, gdy obaj poprzedni ojcowie już zajmowali stanowiska biskupei, kontynuował swoją pracę. W jednym z listów św. Grzegorz Teolog napisał do niego, że przedłużając swoją pracę retora zachowuje się niefilozoficznie, nie wybiera trudnego życia w posłudze dla innych, życia chrześcijańskiego, ale pozostaje retorem by zyskać ludzką chwałę, co nie jest godne filozofa. Jako retor musiał być Grzegorz obeznany doskonale z nauką starożytnych, może dzięki temu, uznaje się go za największego filozofa wśród kapadocczyków. Grzegorz z Nyssy rzeczywiście odróżnia się $\mathrm{w}$ swych pismach od poprzedników, w przeprowadzonym przez niego wykładzie nauki chrześcijańskiej można dostrzec metodologiczne i merytoryczne podobieństwo do Filona z Aleksandrii i Platona.

Święty Grzegorz w swym dorobku pisarskim dokonuje twórczej przeróbki nauki filozofów. O ile jego starszy brat i imiennik z Nazjanzu cytował niejednokrotnie

\footnotetext{
28 Tamże.

29 Por. Tamże, s. 48-49.

30 Zob. Tamże, s. 49

31 Zob. Tamże, s. 220.

32 Tamże, s. 265
} 
filozofów starożytnych przyrównując ich naukę z nauką chrześcijan, to Grzegorz z Nyssy stara się raczej nie porównywać, a wkomponowywać, dopasowywać dotychczasową filozofię do Pisma Świętego, uzgadniał ją z mistycznym doświadczeniem Boga. Znając filozofię starożytną traktował ją globalnie, nie mógł niektórych pojęć albo poglądów zgodnych z objawieniem przyjąć i uznać za chrześcijańskie, bo są one owocem całości systemu filozoficznego. Nie można przyjąć pojęć i zapomnieć o rzeczywistości w jakiej funkcjonowały, bo filozofia jest metodą porządkowania światopoglądu $\mathrm{w}$ precyzyjny, logiczny i całościowy system. Będąc przez długi czas retorem Grzegorz nie mógł podejść lekkomyślnie do filozofii, chcąc pokazać teorię nauki chrześcijańskiej nie mógł ograniczyć się do ukazania jej podobieństwa do nauki starożytnej. Konfrontacja poglądów jest konieczna, ale Grzegorz ukazuje naukę chrześcijańską jako nowy horyzont postrzegania świata, człowieka i Boga, dla którego konfrontacja, ale i zapożyczenie części poglądów od filozofów, nie wystarczają. Co prawda w nauce antropologicznej w szczególności, oraz w nauce dogmatycznej pojawiają się zbieżności z Platonem i Filonem, jednak mimo to nie jest to ich kontynuacja ani rozwijanie. Grzegorz bazuje na pojęciach filozoficznych, ale nie odwołuje się do poglądów Hellenów. Stara się ukazać na sposób filozoficzny czym jest chrześcijaństwo, by móc je porównać do zamkniętych i skończonych systemów filozoficznych starożytności. Trzeba przyznać, że dokonuje tego w sposób perfekcyjny, nie gorszy niż klasycy filozofii, co stawia jego naukę na wysokim poziomie filozoficznym.

Grzegorz kontynuuje dzieło swego brata i Grzegorza Teologa, w dziele „O stworzeniu człowieka” rozwija pominięta przez Bazylego naukę antropologiczna $a^{33}$, w liście skierowanym do pogan tłumaczy wiarę chrześcijan w Trójcę Świętą ${ }^{34}$, zaś w słynnym „Żywocie Mojżesza” rozwija naukę o duszy i analizuje mistyczną wędrówkę duszy do Boga. W tym też dziele ustosunkowuje się do filozofii helleńskiej, którą traktuje jako cenny owoc kultury pogańskiej, przygotowujący i wprowadzający człowieka na mistyczną ścieżkę poznania Boga. Korzysta z prac filozoficznych i wykorzystuje je do opisu nowych treści. Można się pokusić o stwierdzenie, że św. Grzegorz nie musi cytować filozofów, ani odwoływać się do ich poglądów, bo sam jest jednym $z$ nich, a nawet wyprzedza ich intelektem. Nie musi poszukiwać wśród filozofów poparcia dla własnej nauki, ani nie musi zwalczać ich poglądów, bo jako filozof ma świadomość prawdziwości swoich poglądów. Mając na uwadze słowa św. Grzegorza z Nazjanzu, że filozof powinien swej nauce poświęcić życie ${ }^{35}$, biskup Nyssy porzuca spekulatywną filozofię i nie zajmuje się nią więcej. Bazując na swoim intelektualnym doświadczeniu wykorzystuje je w służbie objawieniu. Zapewne dlatego św. Grzegorz

\footnotetext{
3 Por. Św. Grzegorz z Nyssy, O stworzeniu człowieka, Wydawnictwo WAM, Kraków 2006, s. 48.

34 Zob. Свт. Григорий Нисский, К эллинам, www.krotov.info/ library/04_g/gri/gor_nissky_02.html.

35 Por. Św. Grzegorz z Nazjanzu, Listy, Jan Jachowski Księgarnia Uniwersytecka, Poznań 1933, s. 22.
}

w swych tekstach dogmatycznych bardzo często cytuje Pismo Święte, a przytaczanie dzieła filozoficznych ogranicza do minimum (choć treści starożytnych jest u niego co nie miara).

Ojcowie Kapadoccy rozpoczęli proces dialogu nauki chrześcijańskiej z kulturą grecką, rozwinęli teoretyczny po części praktyczny dyskurs, który w przyszłości został nazwany dyskursem patrystycznym. Jako filozofowie potrafili odnieść się pozytywnie do filozofii,rozwijając ją i ukierunkowując na nową drogę. Wyciągnęli z niej najcenniejsze treści, które pozwoliły wypracować nowy styl prowadzenia myśli, argumentacji swoich poglądów, stworzyli to, co nazwać można orthodoksią. Wszyscy późniejsi pisarze będą bazować na wypracowanej przez nich terminologii, zaś myśliciele prawosławni do dziś, tłumacząc czym jest prawosławie nie mogą nie nawiązać do trzech powyższych filozofów-teologów. Zwracając uwagę na intelektualną wartość tych pisarzy nie należy zapominać o drugim, przeze mnie nie wspominanym, ale równie ważnym aspekcie działalności Ojców Kapadockich. Każdy $\mathrm{z}$ nich był mnichem, mistykiem, praktykiem głoszonej nauki. Źródła ich inspirujące znajdują się nie tylko w nauce teoretycznej, ale w głębokim, osobistym kontakcie z Bogiem. Można powiedzieć, że doświadczenie duchowe było pierwotne, dopiero impuls od niego płynący motywował Ojców do rozpoczęcia działalności intelektualnej. Byli więc oni filozofami, według św. Grzegorza z Nazjanzu, nie należy jednak podkreślać ich intelektualności, chyba że w celu ukazania równości z filozofami klasycznymi. Bowiem podjęli się oni próbę przeinterpretowania kultury antycznej, nadania jej innego, nowego, chrześcijańskiego sensu. Ich celem nie było zajęcie miejsca wspólnego z Sokratesem, Platonem czy Arystotelesem, ponieważ podążali śladami Abrahama, Mojżesza i Pawła. Filozofia pogańska była dla nich ćwiczeniem umysłu, sama zaś filozofia, jako metoda, stała się receptą na życie, które umożliwi poznanie Boga. Ukazana i dokonana przez nich synteza praktyki i teorii chrześcijańskiej jest do dziś przykładem tego, jaką powinna być myśl prawosławna.

\section{Inni Ojcowie Kościoła wobec tego samego problemu}

Trzej Ojcowie z Kapadocji zapoczątkowali rozwój wschodniej myśli chrześcijańskiej, jak łatwo zauważyć zaproponowana przez nich metoda odbiegała nieco od metody zachodniej, którą trochę później obrał Augustyn. Ojcowie nie starali się odnaleźć najbardziej pasującej do poglądów chrześcijan filozofii i na jej gruncie rozwinąć myśl biblijną, tak jak zrobił Augustyn na Zachodzie, ale chcieli rozwijać myśl biblijną posiłkując się najlepszymi owocami filozofii i kultury greckiej w ogóle. Pozytywny stosunek do filozofii nie oznaczał przyjęcia pogańskiego światopoglądu, 
z jakiego wyrosła filozofia, a oznaczał chęć przeniesienia filozofii na nowy grunt religii judeochrześcijańskiej. Filozofia tych Ojców podkreślała swój objawiony charakter, była na wskroś chrześcijańska, ponieważ zmienione zostały jej podstawy. Już nie sam rozum, jak w starożytności, ale rozum posiłkujący się objawieniem, a nawet dający objawieniu pierwszeństwo. Tak powstała teologia prawosławna, która taki charakter zachowuje do dziś. Już w IV wieku zauważamy rozchodzenie się sposobu uprawiania filozofii -teologii na Wschodzie i na Zachodzie. Od Augustyna metoda filozoficzna zostanie przyjęta na Zachodzie i uznana za jedynie słuszną, zaś dociekliwy umysł grecki ciągle poszukuje, dopatruje się różnic w sposobie mówienia o Bogu u filozofów i u chrześcijan.

Drogą Ojców z Kapadocji będą podążać wszyscy następni Ojcowie Kościoła. Zmieni się jednak u nich sposób pojmowania filozofii, która będzie utożsamiana $\mathrm{z}$ religią pogańską i będzie przybierała negatywne znaczenie. Jedni będą potępiać wszystko, co jest związane w jakikolwiek sposób z filozofią, zaś drudzy będą się do niej przyznawać i rozwijać. Problem z filozofią zacznie się w V wieku, gdy wśród mnichów egipskich popularność zyska filozofia Orygenesa.

Neoplatonizm w ujęciu chrześcijańskim, czyli orygenesowski system, okazał się czymś obcym ludziom Kościoła. O ile oczywiste krytykowano Platona, Arystotelesa i innych, z uwagi na ich błędne, niebiblijne koncepcje Boga, nieba, świata i człowieka, to z trudnością można było przytoczyć argumenty przeciwko Orygenesowi, który jeszcze w V wieku nie był potępiony, a jego pisma cieszyły się ogromnym autorytetem. Okazało się, że filozofia pogańska nie była problemem, dla filozofii chrześcijańskiej Bazylego i obydwu Grzegorzy.

Chrześcijański neoplatonizm groził skażeniem obrazu Boga i Chrystusa, a w konsekwencji spekulatywno-mistyczną praktyką duchową, o co oskarżano właśnie mnichów egipskich. Noetyczny charakter modlitwy, polegający na umniejszeniu roli ciała w praktyce duchowej oraz na platońskim dążeniu do oderwania duszy od ciała, do ektazy, odróżniał modlitwę orygenistów od praktyki modlitewnej św. Makarego Wielkiego i jego kontynuatorów, dla których serce, a nie umysł, było organem modlitwy i centrum człowieka. Jak zauważył ks. J. Meyendorff w swojej książce o św. Grzegorzu Palamasie, recepcja filozofii przez mnichów chrześcijańskich doprowadziła do wypracowania, a następnie konfrontacji dwóch antropologii, pierwszej biblijnej i drugiej platońsko-idealistycznej ${ }^{36}$. W pierwszej akcent był położony na syntezę człowieka jako stworzenia psychosomatycznego, zaś w drugiej akcent przesunięty na aktywność umysłu (voúc), który ma na celu, porzuciwszy więzienie ciała, powrócić do swego Stwórcy.

Filozofia neoplatońska wywierała duży wpływ na tylko co schrystianizowane Cesarstwo, przypominała tym samym o dawnych zasadach kultury helleńskiej, które od czasów cesarza Teodozjusza Wielkiego zostały odrzuco-

\footnotetext{
36 Zob. Иоанн Мейендорф, Жизнь и учение свт. Григория Паламы, ВИЗАНТИНОРОССИКА, Санкт-Петербург 1997, s. 191-194.
}

$\mathrm{n}^{37}$. Z tego powodu utrzymująca się w szkołach w Atenach i Aleksandrii filozofia neoplatońska była ostatnią nicią łączącą Cesarstwo pogańskie z chrześcijańskim, a jej wpływ na myśl chrześcijańską i pojawiające się nieustannie herezje były czynnikiem działającym na jej niekorzyść. To właśnie w filozofii dopatrywano się negatywnego wpływu na kulturę Cesarstwa. Stąd właśnie wzięła się niechęć do filozofów, a nawet ich prześladowanie, które od $\mathrm{V}$ wieku stało się metodą ich zwalczania w Cesarstwie.

Dobrym przykładem tego może być osoba św. Cyryla Aleksandryjskiego, który sam nie będąc umysłem ścisłym i filozoficznie przygotowanym do obrony ortodoksji, nie potrafiącym precyzyjnie wytłumaczyć swej prawidłowej intuicji teologicznej, musiał nadrabiać te braki aktywnością polityczną i działalnością praktyczną. Obawa przed filozofią pogańską była na tyle silna, że w Aleksandrii tłum, zniechęconych do filozofii niechrześcijańskiej, zamordował neoplatońską filozofkę Hypatięę, co do dziś wielu historyków i myślicieli niechrześcijańskich zarzuca św. Cyrylowi. Przykłady Hypatii, jak również Jamblicha ${ }^{39}$ i Proklosa, scholarów Akademii, którzy, choć nie zamordowani,lecz potępiani, świadczą o tym, że filozofia w dobie chrześcijańskiej nie była pozytywnie postrzegana. Z pewnością takie podejście do filozofii bierze się stąd, że filozofowie chcieli za wszelką cenę zachować swój pogański charakter. Starali się usystematyzować życie duchowe Greków, ukazywali inne, niechrześcijańskie drogi poznania Boga, zaś samego Boga nie postrzegali jako Bytu osobowego, ale Absolut, obcy im był charakter chrystologiczny teologii. Zapewne to tworzenie alternatywnego wobec chrześcijaństwa systemu podtrzymywało napięcie wobec filozofii i teologii. Wydaje się też, że już od tych czasów zaczyna się proces rozchodzenia się dróg filozofii świeckiej i teologii.

Choć późniejsi Ojcowie Kościoła to wykształceni filozofowie, to jednak oficjalnie nie byli nimi, tak jak ojcowie Kapadoccy. Obrona ortodoksji przed herezjami wymagała wnikliwości i umiejętności rozróżnienia subtelnych niuansów językowych, które nie odpowiadały chrześcijańskiemu objawieniu. Filozoficzne przygotowanie było niezbędne dla uczonych chrześcijańskich, ponieważ umożliwiało im zrozumienie istoty problemu. Ojcowie byli najwybitniejszymi umysłami swojej epoki, stali się kontynuatorami filozofów starożytnych $\mathrm{w}$ pragnieniu poznania Boga, ale ukazali też w swej nauce możliwość prawdziwego spełnienia, które dla starożytnych było nieosiągalne.

Wraz z rozwojem neoplatonizmu wśród chrześcijan co-

\footnotetext{
Według prawodawstwa cesarza Teodozjusza wszystkie pogańskie świątynie zostały zamknięte, a składanie ofiar zostało zabronione, tym samym został zakończony etap kultury helleńskiej, a rozpoczął się etap kultury chrześcijańskiej. Słowo „kultura”, wg o. Pawła Florenskiego, pochodzi od „kultu”, co znaczy, że kultura bierze swój początek od religii i związanego z nią kultu. Dlatego odrzucenie kultu pogańskiego świadczy o rezygnacji z całości dotychczasowej kultury.

38 Zob. А. Дворкин, Очерки по истории Вселенской Правиславной Церкви, Нижний Новгород 2005, s. 275-276.

39 Imię Jamblicha niejednokrotnie pojawia się w tekstach liturgicznych, w celu potępienia jego herezji. Jeżeli zaś przyjmiemy, że główny filozof Akademii uznawany był za heretyka, to podobnie zapewne była postrzegana wówczas filozofia.
} 
raz modniejszy stawał się arystotelizm. Począwszy od VII wieku w Bizancjum zaczyna się zwrot w kierunku Arystotelesa. Św. Jan z Damaszku, który w swych pismach licznie odwołuje się do Stagiryty, w dziele „Źródło wiedzy” dokonuje filozoficznego wprowadzenia do dogmatyki, wyjaśnia podstawowe dla Ojców pojęcia filozoficzne, przy czym nawiązuje do neoplatonika Porfiriusza ${ }^{40}$. Filozofia przez cały czas była ważnym punktem odniesienia dla teologów chrześcijańskich, bowiem umożliwiała chrześcijaństwu rozwinięcie własnej myśli i precyzyjne zdefiniowanie przedmiotów wiary.

Na gruncie chrześcijańskim rozwijał się także inny niż teoretyczny rodzaj dyskursu należący do pisarzy okresu patrystyki. Ten dyskurs dotyczy egzystencjalno-doświadczalnej nauki, którą spisali twórcy nurtu ascetycznego. Często byli to ludzie, nie zawsze wykształceni filozoficznie, ale potrafiący dokładnie wyrazić intuicję duchową. W swoich dziełach nie tłumaczyli dogmatów, a opisywali praktyki duchowe. Modlitwa, pokuta, panowanie nad namiętnościami, oczyszczeniu umysłu - taką tematyką zajmowali się ci pisarze. Teksty zawarte w „Filokaliach” są opisem przeżycia mistycznego, wśród tych twórców nie znajdziemy odwołań do filozofii, ani jej krytyki, ale dostrzeżemy praktyczne zalecenia dotyczące życia chrześcijańskiego. Nawoływanie do ciszy umysłu, wyzbycia się wszelkich wyobrażeń i wszelkiej aktywności rozumu jest stanem, do jakiego modlitwa ma doprowadzić człowieka. Ciągły wysiłek dążący do udoskonalenia człowieka jest cechą charakterystyczną ascetów wschodnich. Doskonałość jednak nie polega na rozwoju intelektualnym, a na możliwie najlepszym przypodobaniu się Bogu, polega na dostrzeżeniu Boga i pełnym zjednoczeniu się z Nim. Nie ma tu mowy o filozofii, choć u części pisarzy pojawia się terminologia filozoficzna, ale z pewnością nie ma nawoływań do rozumowych rozważań tego typu, są one nawet niewskazane. Takie podejście do filozofii jest charakterystyczne dla pisarzy monastycznych do dnia dzisiejszego, już w Bizancjum bardzo się rozprzestrzeniło i skutkowało wspomnianą już wcześniej niechęcią do filozofii. Pełny wyraz takiej myśli można znaleźć w „Triadach” św. Grzegorza Palamasa, który jako mnich z Góry Atos bronił praktycznego, a nie teoretycznego poznawania Boga, ale jako teolog nie omieszkał wytłumaczyć współczesnym mu ludziom sposobu poznawania Boga. W ten sposób w swej nauce dokonał syntezy patrystyki i ascetyki, w czym okazał się wiernym naśladowcą wielkich Kapadocczyków.

\section{4. Święty Grzegorz Palamas}

Ostatni Ojciec Kościoła, jakim można nazwać św. Grzegorza, znalazł się w nieco innej sytuacji niż jego poprzednicy z IV wieku. Kapadocczycy tworząc dyskurs teologiczny, musieli bazować na czymś, co już istniało, dlatego za wzór obrali dyskurs filozoficzny. Korzystali z pojęć

\footnotetext{
40 Filozof neoplatoński, żyjący w IV w., komentator dzieł Platona i Arystotelesa, najważniejszy myśliciel dla filozofów średniowiecznych.
}

wypracowanych przez starożytnych filozofów, nadali tym pojęciom inny, nowy sens, ale także korzystali z nauki filozoficznej, która umożliwiła im uargumentowanie nauki płynącej z Pisma Św. Metoda filozoficzna stała się ich własną metodą, tylko że posługiwała się inną treścią. Przez niespełna dziesięć stuleci oddzielających Palamasa od Ojców Kapadockich, myśl chrześcijańska żywiołowo się rozwijała, przyjęła dojrzałą formę, a co najważniejsze zdołała się zdystansować i zróżnicować w stosunku do myśli filozoficznej. Jeszcze w IV wieku Ojcowie nazywali siebie filozofami, zaś już ok. dwieście lat po nich filozofię zaczęto uważać za niegodną porównywania z chrześcijaństwem. Jeszcze Jan z Damaszku nawiązywał do klasyków filozofii, ale już po nim nie pojawił się aż do dwudziestego wieku nikt, kto by otwarcie nawiązywał w nauce do filozofii. Święty Grzegorz Palamas także krytycznie odnosi się do mądrości greckiej, pod którą rozumiał nauki filozofów niezgodne z objawieniem.

Na pojawiającą się herezję Barlaama święty reaguje stanowczo. Dostrzega u jej podłoża wpływ hellenizmu, filozofii, który nie był w stanie przetrawić mistycznego doświadczenia chrześcijańskiego. Barlaam, będący pod wielkim wpływem zachodniego nominalizmu, jak i również teologii apofatycznej, nie mógł zrozumieć praktyki duchowej mnichów atoskich, którzy głosili, że podczas modlitwy widzą Boga, a ściślej Bożą światłość. Barlaam uznawał jedynie naturalne poznanie Boga, które, poparte Pismem Świętym, umożliwiało człowiekowi maksymalne poznanie Stwórcy. Według niego rozum jest instancją poznającą i jedynie to, co on dyktuje można poznać, zaś wszelkie wizje i widzenia mają charakter demoniczny i zwodniczy, oszukują człowieka. Bo przecież jak można poznać niepoznawalnego, Którego nawet biblijni prorocy i święci nie widzieli? To pytanie okazuje się kluczowe podczas czternastowiecznych sporów teologicznych. Barlaam atakując mnichów i negując możliwość bezpośredniego poznania Boga, okazuje się umysłem niechrześcijańskim, nie potrafiącym zrozumieć istoty prawosławnej myśli - Bogoczłowieczeństwa Jezusa Chrystusa, Który naturę ludzką podniósł do godności Bożej, przebóstwił i uczynił współuczestniczącą wieczności.

Uznając Barlaama za jednego z filozofów Palamas odrzuca wraz z nim całą filozofię grecką, na którą się on powołuje. W czasach św. Grzegorza szczególnie podkreślano różnicę, tematyczna między filozofią i teologią. Dlatego święty w „Triadach” daje wyraz szczególnie popularnej w jego czasach opinii, że filozofowie nie potrafili pojąć tego, co pochodzi od Ducha, a jedynie ograniczali się do kwestii przyziemnych, dlatego prawdziwą mądrość uważali za głupotę i ją wyśmiewali. A przecież „wiedza, zdobywana przez naukę zewnętrzną, jest nie tyle niepodobną, co nawet przeciwstawną wiedzy prawdziwej i duchowej, chociaż niektórzy, co widać, sami zbłądziwszy w pogoni za nią i starający się oszukać nią swych uczniów, rozważają o niej jakby była tą samą (prawdziwą - Ł.L.) wiedzą, ogłaszając ją za cel kontemplacji" ${ }^{41}$. Filozofowie tak nauczający służą

41 Св. Григорий Палама, Триадь. В защиту священно-безмолвствующих, НАУКА, Санкт-Петербург 2004, s. 19. 
złemu duchowi, pisze dalej święty Grzegorz, a tym samym odłączają się od prawdziwej wiedzy chrześcijan. Święty dokonuje analizy poglądów Sokratesa i Platona, którzy nauczając o preegzystencji i wielokrotnym wcielaniu się dusz, nic wspólnego nie mają z nauką apostolską. Dokonując nad nimi osądu, Palamas nie zamierza ich cytować w celu podniesienia rangi swojej nauki, a wręcz przeciwnie, oskarża starających się ukazać podobieństwo filozofii i objawienia. Przykładem tego mogą być święci apostołowie Paweł i Barnaba, którzy znając przejawy złych mocy „nie przyjęli kobiety, która mówiła o nich, że ci ludzie są sługami Boga Najwyższego, mimo, że cóż, wydawałoby się, może być bardziej pobożne nad te słowa? Jednak apostołowie rozpoznali „tego, który przyjmuje postać anioła światłości” i jego sługi, starających się podejść do „sług prawdy" i odrzucili słowa prawdziwe jako będące nie na miejscu na ustach kłamliwych"². Filozofowie mogli głosić treści zgodne z nauką chrześcijańską, ale cóż z tego, jeżeli poprzez życie wewnętrzne nie poznali prawdy. Przecież demony także wyznawały Chrystusa, jako Syna Bożego, ale cały czas pozostawały demonami. Porównanie filozofów do złej siły, która choć mówi prawdę, ma na celu sprowadzić człowieka na złą drogę, jest bardzo skrajnym sądem, ale w pełni oddającym stosunek prawdy objawionej do prawdy domniemanej. „Dlatego my - pisze św. Grzegorz - słysząc pobożne słowa $\mathrm{z}$ ust Hellenów, ich samych nie uznajemy za pobożnych, ani do nauczycieli ich nie zaliczamy, dlatego, jak wiemy, że wszystko to oni zapożyczyli od nas - nie na darmo któryś z nich powiedział o Platonie: „Kim jest Platon, jeśli nie attyckim Mojżeszem?”, - choć my, powtarzam, wiemy, że jeżeli jest u nich cokolwiek dobrego, to usłyszeli to od nas, jednak, przypatrzywszy się dostrzegamy, że zrozumieli to wszystko nie w tym samym sensie. A gdy któryś z Ojców mówi to samo co filozofowie, to jest to tylko zgodność słów, bo w ich sensie różnica jest wielka: u jednych jest, według słów Pawła, „umysł chrystusowy", a drudzy głoszą z własnego rozumu, jeśli nie gorzej”33.Wszyscy ci, którzy opierają się na zasadach filozofii nie mają nic wspólnego z prawdą, wymagającą oczyszczenia, pokuty oraz pokory rozumu. Filozofowie zaś, którzy nie potrafią zrozumieć sług Słowa, oczerniają ich, oskarżają, stając się dla Palamasa, wrogami Pisma Świętego ${ }^{44}$. Filozofia jest aktywnością rozumu człowieka, zaś św. Grzegorz broni hezychazmu, metody, która polega na wyciszeniu wszelkich poruszeń ciała, duszy, woli i rozumu, w celu odnalezienia w sobie Boga. Żadna filozofia nie poucza nas o czymś takim, jedynie chrześcijaństwo daje podobną możliwość: ,jeśli mimo oczyszczenia przez cnotę nie staniemy wewnątrz, a dokładniej ponad samych siebie, pozostawiając jednocześnie z odczuwaniem wszystko zmysłowe, podnosząc się nad zamysłami, rozważaniami i wiedzą rozumową, całego siebie oddawszy się w modlitwie niesubstancjalnym działaniom [energiom] duchowym, otrzymawszy niewiedzę, która przewyższa wiedzę, i napełniwszy się w niej naj-

\footnotetext{
42 Tamże, s. 20.

43 Tamże, s. 21.

44 Por. Tamże, s. 27.
}

światlejszą jasnością Ducha, w taki sposób, że niewidzialnie dostrzeżemy nagrody świata wiecznego" ${ }^{45}$. Wyraźnie brzmią słowa przedkładające modlitwę nad spekulatywne dociekania filozoficzne, które są już nie tyle niewskazane, ile niepotrzebne, a nawet niebezpieczne. „To na co komu droga, jeśli nie prowadzi do świątyni?" 46 - pytała staruszka w kończącej film scenie, zaś św. Grzegorz zdaje się pytać po co komu nauka, która nie umożliwia poznania Boga? Najprostsza teoria, mieszcząca sedno myśli chrześcijańskiej, nie dotyczy budowania intelektualnie wartościowych i zawikłanych systemów, ale dążenia ludzkiego serca do swego Stwórcy, który stał się stworzeniem. Cała pierwsza triada poświęcona jest krytyce filozofii, św. Grzegorz chce oczyścić sobie drogę przed rozpoczęciem wykładni prawosławnej nauki o przebóstwieniu. Z pełną świadomością odrzuca myślenie filozoficzne, wchodzi jednocześnie w dyskusję z współczesną mu filozofią. W sporach z Barlaamem musi stawić czoła zachodniej, ale także wschodniej filozofii, jej odrzucenie nie jest jedynie podyktowane niechęcią emocjonalną, jest bowiem intelektualnie przygotowane, uargumentowane i spójne logicznie. Można powiedzieć, że ta krytyka opiera się na egzystencjalnym przeświadczeniu, że wielka mądrość ludzka jest niczym wobec doświadczenia Boga. Palamas bazuje na swoim własnym doświadczeniu, można stwierdzić, że pisząc „Triady” kontynuuje apologetów, a obrana przez niego metoda jest obca i daleka współczesnej mu myśli filozoficznej.

W kolejnych triadach św. Grzegorz, uporawszy się z „baśniami filozoficznymi”, rozpoczyna wykład o światłości Bożej, o istocie i energiach. Ciekawym wydaje się fakt, że po posuniętej do granic możliwości krytyce filozofii, następuje zwrot w prowadzeniu dyskusji. Po zasygnalizowaniu tego, co jest dla niego najważniejsze - obrona praktyki hezychastów - rozpoczyna już w nieco łagodniejszym tonie rozważania teoretyczne nad treściami doświadczalnymi w praktyce modlitewnej. Bezpośrednie objawienie Boga staje się dla św. Grzegorza materiałem, który należy precyzyjnie opisać, wytłumaczyć tym, którzy nie rozumieją. Dlatego święty nie może obejść się bez zaplecza intelektualnego współczesnej mu epoki. W młodości będąc wykształconym filozoficznie arystotelikiem, zapożycza terminologię i metodę Arystotelesa, która umożliwi mu dokonanie analizy treści doświadczenia duchowego. Palamas dyskutuje z Arystotelesem, nazywając go ciągle filozofem, nie przyjmuje jego nauki, a w dyskusji z nią tworzy swoją, albo jak kto woli rozwija arystotelizm, ale na gruncie chrześcijańskim. Odwołuje się do kategorii arystotelesowskich, które twórczo upowszechnia. Jego nauka o energii jest rozwinięciem rozpoczętej przez Stagirytę kwestii, zaś pojęcie istoty rozumie tak jak w „Metafizyce” Arystoteles. Św. Grzegorz nie cytuje Arystotelesa, ale z pamięci przywołuje jego poglądy, w drugiej części swego dzieła jest jak najbardziej filozoficzny, ale nie w sensie metody czy poglądów, a w sensie rozumienia kluczowych problemów. Palamas w pierwszej części „Triad”, odrzucając filozofię,

\footnotetext{
45 Tamże, s. 115.

46 Cytat z ostatniej sceny filmu „Pokuta” z 1986 r. zrealizowanym w ZSSR.
} 
wypracował swoją metodę, inną niż metoda Barlaama. Ten drugi przez spekulatywne myślenie dochodzi do wniosków na temat Boga, poznanie naturalne skłania go do mówienia o Bogu. Grzegorz zaś posługuje się metodą niespekulatywną, a egzystencjalno-introspekcyną. Dopiero wgląd w siebie, doświadczenie Bożej obecności wyzwala możliwość opisania Boga. Metodologicznie Grzegorz jest podobny do dwudziestowiecznych fenomenologów żyjąc jednak w XIV-tym w. nie mógł tej metody zapożyczyć od filozofów, a od pisarzy ascetycznych piszących nieprzerwanie od IV w.

Nieprzyjazny stosunek do filozofii łagodnieje w drugiej części dzieła życia św. Grzegorza, jednak nawet tam, korzystając z antycznych wzorców, bogowidienije ma prymat nad filozofią. W ten sposób będą tworzyć pisarze prawosławni po Grzegorzu, zaś w naszych czasach ten rodzaj „filozofowania” odrodzi się po długiej przerwie wśród pisarzy rosyjskich, należących do tzw. pisarzy neopatrystycznych, za których uznaje się mnicha Bazylego Krywoszeina, Włodzimierza Łosskiego i ks. Johna Meyendorfa. Po latach zastoju w rozwoju myśli prawosławnej, w połowie wieku dwudziestego, nastąpiło odrodzenie myśli palamickiej. Wiązało się to z nową falą recepcji Ojców Kościoła, która nadeszła wraz z rozwojem filozofii rosyjskiej. Ponownie prawosławni teologowie stanęli przed pytaniem: „Którą drogą podążać?”. Wzór Ojców, ich podejście do rozwiązywania problemów kultury, przefiltrowywania tego, co niechrześcijańskie, nadawanie ortodoksyjnego sensu i wartości oraz odważne wchodzenie w dialog z aktualnymi nurtami filozoficznymi stało się czymś, co należało odrodzić. Wymienieni wyżej pisarze, a w szczególności dwaj ostatni w swych znanych nam książkach „Teologia mistyczna” i „Teologia bizantyjska” dokonali odrodzenia myśli patrystycznej, nie starali się jej ślepo naśladować, a kontynuowali ją wchodząc $\mathrm{w}$ dyskusję $\mathrm{z}$ współczesną nauką i filozofią. W epoce patrystycznej Ojcowie spierali się z Platonem i Arystotelesem, zaś w dwudziestym wieku filozofia dostarczyła swoje współczesne owoce, które należało przeanalizować, ustosunkować się do nich, a w razie potrzeby skrytykować i potępić. Ciekawym jest fakt, że to właśnie myśl św. Grzegorza okazała się najbardziej trafną w tej dyskusji. Można zauważyć więc, że nauka św. Grzegorza była swoistym zwieńczeniem patrystyki, jej syntezą az scetyką, a tym samym tym, co dziś nazywa się myślą prawosławną. Prawosławie w XIV w. otrzymało swoją formę w nauce o przebóstwiających człowieka energiach Bożych. Paradoks dotyczący owej nauki, polega na tym, że w XX w. prawosławny energetyzm okazał się podstawą dla rozwoju ortodoksyjnej myśli i został przejęty przez filozofię. To, co w XIV w. było owocem krytyki filozofii sześć stuleci później okazało się jej podstawą (i to nie tylko prawosławnej, ale i laickiej).

Powyżej staraliśmy się zwrócić uwagę na to, że stosunek Ojców i pisarzy chrześcijańskich wobec filozofii nie był jednorodny, jak chce się go bezrefleksyjnie przedstawiać. Na przestrzeni wieków można znaleźć pisarzy, któ- rzy odnosili się do myśli filozoficznej z aprobatą i takich, którzy pałali do niej niechęcią. Jedni z nich zostali świętymi filozofami, jak np. Justyn Filozof czy Grzegorz z Teolog, także drudzy zajęli obok nich miejsce. Rozumieli oni filozofię bardzo różnie - jako dążenie do Bożej Mądrości, którą jest Chrystus, jako metodę umożliwiająca interpretację objawienia oraz całościową postawę życiową, połączoną z cierpieniem i samowyrzeczeniem. Najczęściej jednak filozofia była postrzegana historycznie, jako nauka myślicieli pogańskich o poglądach kosmologicznych, teologicznych i antropologicznych. Tak rozumiana budziła krytykę prawie każdego myśliciela chrześcijańskiego, bowiem bezrefleksyjne przejęcie nauk starożytnych przez chrześcijaństwo okazywało się brzemienne w skutkach - stwarzało warunki do powstawania i rozwoju herezji, wynaturzało objawienie i relację człowieka do Boga. Z tych też względów w okresie zaawansowanej patrystyki filozofia zaczęła być synonimem herezji. Jednak sam sposób myślenia, rozumowego ujmowania nauki o Bogu pozostał filozoficzny do końca patrystyki, a i dziś także nie jest obcy teologom prawosławnym.

Okazało się, że samo zapożyczenie pojęć od filozofów greckich nie było możliwe, ponieważ były one uwikłane w pewną, konkretną rzeczywistość filozoficzną. Zetknięcie się chrześcijaństwa z Grecją sprawiło, że należało mówić do otaczającego świata w jego, nie tylko państwowym, ale przede wszystkim teoretycznym języku. To „spotkanie” doprowadziło do zmiany myśli chrześcijańskiej, odróżniło ją od myśli żydowskiej, a przybliżyło do myśli filozoficznej. Do dziś mówiąc o Bożej istocie, chcąc prawidłowo zrozumieć czym ona jest, odwołujemy się do realności filozoficznej, wszystkie pojęcia teologiczne mają swój źródłosłów w filozofii starożytnej. Zapewne gdyby chrześcijaństwo spotkało się z hinduizmem, to charakterystyczne dla tej myśli pojęcia znalazłyby się u podstaw teologii chrześcijańskiej, oczywiście w zmienionym sensie. Mimo bliskiej zawiązanej między filozofią i ortodoksją, żadna z tych dziedzin nie podporządkowała się drugiej. W prawosławiu dwie sfery - filozoficzna (w sensie metodologiczna) i teologiczna rozwijają się w swoim rytmie, wzajemnie uzupełniając się. W prawosławiu nie doszło do wchłonięcia teologii przez filozofię, jak na Zachodzie, a przez cały czas pozostaje równowaga między nimi. Umożliwia to rozwój myśli świeckiej, która nie pretendując do miana objawionej, staje się polem penetracji teologicznej, mającej na celu owoc intelektualnego wysiłku człowieka podnieść do Stwórcy i przez Jego uświęcającą łaskę dokonać weryfikacji. Filozofia zaś dążąca do miana objawionej zawsze w Kościele spotykała się z krytyką, ponieważ zakładała inny fundament, niż wychwalana, przez nią Mądrość. Ojcowie zawsze pod pojęciem umiłowanie mądrości dopatrywali się Chrystusa, wcielonego Boga, od umiłowania Którego rozpoczynała się wszelka mądrość ${ }^{47}$. Dlatego główną świątynię Bizancjum, świątynię Mądrości Bożej, jako alternatywę ateńskiej Akademii, możemy nazwać świątynią filozofów, tych którzy umiłowali Bożą

\footnotetext{
47 Por. Eklezjastyk 1,14.
} 
Mądrość. Zamknąłby się wtedy krąg myśli; apostoł Paweł przyszedłszy do Aten zwrócił uwagę filozofów na świątynię poświęconą nieznanemu Bogu, jego uczniowie po stuleciach walk poświęcili swoją świątynię Bogu znane- mu, do którego przyprowadzili tychże filozofów, a potem umieszczali ich nawet na ścianach swych świątyń pośród świętych.

Rozmiar artykułu 1,7 arkusza wydawniczego 